Med Klin Intensivmed Notfmed 2020 115:519-525 https://doi.org/10.1007/s00063-020-00711-1 Online publiziert: 18. August 2020 (c) Springer Medizin Verlag GmbH, ein Teil von Springer Nature 2020

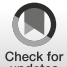

\section{Akzeptierte Abstracts für die COVID-19-bedingt abgesagte DGIIN/ÖGIAIN-Jahrestagung 2020}

Sehr geehrte Leserinnen und Leser,

dieses Jahr hätte die Gemeinsame Jahrestagung der DGIIN und ÖGIAIN als 52. Jahrestagung in Salzburg stattfinden sollte. Leider kam die COVID-19-Krise dazwischen, und trotz der weit fortgeschrittenen Planungen war es unter Einhaltung der gesetzlichen Vorgaben nicht mehr möglich, eine so große Tagung durchzuführen. Die Planungen beinhalteten auch bereits die Evaluierung der eingereichten Abstracts. Da wir trotz der Absage der Tagung die Autoren, die sich der Mühe unterzogen, ihre Arbeiten in einem Abstract zusammenzufassen, nicht leer ausgehen lassen wollten, haben wir uns entschieden, die von den Gutachtern akzeptierten Abstracts in dieser Ausgabe der Zeitschrift Medizinische Klinik - Intensivmedizin und Notfallmedizin zu publizieren. Somit soll den Autoren Gelegenheit gegeben werden, ihre Daten trotzdem einem breiteren Publikum präsentieren zu können.

Nach den derzeitigen Planungen wird die Jahrestagung im Jahr 2022 wieder in Salzburg stattfinden. Wir hoffen, dass uns die Mitglieder der DGIIN und ÖGIAIN dann auch wieder die Treue halten, und wünschen ihnen eine interessante Lektüre mit den Abstracts der heuer leider ausgefallenen Jahrestagung.

\section{Univ.-Prof. Dr. Michael Joannidis}

Präsident ÖGIAIN

Prim. Univ.-Prof. Dr. Andreas Valentin

1. Vizepräsident ÖGIAIN

Tagungspräsident

\section{Real-life use of intravenous (IV) fosfomycin in patients with infective endocarditis - insights from the FORTRESS study}

S. Hagel', S. Kluge' ${ }^{2}$, S. Lindau ${ }^{3}$, F.-A. Litty', K. Bodmann ${ }^{5}$

${ }^{1}$ Universitätsklinikum Jena, Institut für Infektionsmedizin und Krankenhaushygiene, Jena, Germany; ${ }^{2}$ Universitätsklinikum HamburgEppendorf, Zentrum für Anästhesiologie und Intensivmedizin, Klinik für Intensivmedizin, Hamburg, Germany; ${ }^{3}$ Universitätsklinikum Frankfurt, Klinik für Anästhesiologie, Intensivmedizin und Schmerztherapie, Frankfurt, Germany; ${ }^{4}$ InfectoPharm Arzneimittel und Consilium $\mathrm{GmbH}$, Heppenheim, Germany; ${ }^{5}$ Kliniken Nordoberpfalz AG, Klinikum Weiden, Weiden, Germany

Goal of the study: Well-documented clinical data from daily practice on the use of IV fosfomycin in patients with infective endocarditis (IE), particularly with foreign body involvement, are scarce. Here, we present first interim results on the real-life use of IV fosfomycin in a subgroup of critically ill patients with IE.

Methods: Prospective, non-interventional and monitored European multicenter study (FORTRESS; NCT02979951). The primary objective is clinical success, defined as clinical cure or improvement including microbiological cure at the end of fosfomycin treatment (EOT). Secondary objectives are microbiological cure, clinical evaluations at different time points, and safety.

Results: Currently (January 2020), 224 patients with severe infections have been enrolled, including 14 patients with IE ( 3 female, 11 male, mean age 64 years). Of the patients with IE 13 (93\%) were treated in intensive care and $7(50 \%)$ had sepsis or septic shock at baseline. Mean APACHE II score at baseline was 21, $7(50 \%)$ patients had IE associated with a prosthetic valve, $1(7 \%)$ had IE associated with a cardiac device, and $2(14 \%)$ had both. Of the IE 11 (79\%) were left-sided, 1 (7\%) right-sided, and 2 (14\%) were bilateral. Two cases were associated with drug abuse. Five patients had concomitant severe embolic complications and two patients had stroke. Imaging results showed vegetation in $13(93 \%)$ and abscess formation in $1(7 \%)$ case. Twelve (86\%) cases of IE were microbiologically confirmed by indication-relevant samples at the start of fosfomycin treatment. Causative pathogens were mostly staphylococci (11/14 patients $79 \%)$, particularly methicillin-sensitive S. aureus (7/14 patients 50\%) and CoNS (4/14 patients $29 \%$ ). IV fosfomycin was used at a daily dose of $15 \mathrm{~g} /$ day (median) for a mean duration of 17 days and exclusively in combination therapy, particularly with beta-lactams, vancomycin or daptomycin. Clinical success was reported in 11/14 (79\%) patients, thereof in 4/4 patients without foreign body involvement and in 7/10 (70\%) patients with foreign bodyassociated IE. Noteworthy, all 14 patients were microbiologically cured at EOT and 4 (29\%) patients had adverse drug reactions.

Conclusions: These new insights from daily clinical practice suggest that IV fosfomycin is a valuable combination partner for the treatment of IE even in cases of foreign body involvement. 


\section{Modulation des permeabilitätsinduzierenden Faktors Angiopoietin-2 mittels Bifonazol bei systemischer Inflammation}

T. Pape', T. O. Idowu' ', V. M. Etzrodt' ', H. Haller', S. M. Parikh², S. David'

${ }^{1}$ Klinik für Nieren- und Hochdruckerkrankungen, Medizinische Hochschule Hannover, Deutschland; ${ }^{2}$ Beth Israel Deaconess Medical Center und Harvard Medical School, Center for Vascular Biology Research, Boston, USA

Hintergrund: Sepsis ist ein potenziell letal verlaufendes Syndrom bei dem es durch eine pathologische Wirtsantwort auf eine Infektion zu einem Organversagen kommt. Hieran beteiligt ist die Ausschüttung von Angiopoietin-2 (Angpt-2) aus dem Endothel wodurch es zur Deaktivierung des protektiven Tie2-Rezeptors und konsekutiv zu einem schweren Kapillarleck kommt. Eine Angpt-2 modulierende Therapie gibt es bisher nicht.

Durch Screening FDA-zugelassener Medikamente identifizierten wir das Antimykotikum Bifonazol (BIFO) als potenziellen Senker von Angpt-2 in vitro. Wir hypothetisierten, dass BIFO das Kapillarleck über eine Verringerung von Angpt-2 im Blut reduzieren könnte.

Methodik: In aus Nabelschnüren isolierten humanen Endothelzellen (HUVECs) wurden In-vitro-Untersuchungen nach Stimulation mit BIFO durchgeführt (RT-PCR, Immunoblot, ELISA, Immunzytochemie). Invivo-Untersuchungen wurden an $\mathrm{C} 57 \mathrm{Bl} / 6-$ Mäusen nach Stimulation mit BIFO durchgeführt (RT-PCR, Immunoblot, ELISA).

Ergebnisse: In einer dosis- und zeitabhängigen Untersuchung konnten wir nachweisen, dass BIFO die Ausschüttung von Angpt-2 in Ruhe nach 8, 12 und 24 h signifikant senkt (Veh: $15,58 \pm 0,7$ vs. BIFO: $8,56 \pm 0,8 \mathrm{ng} / \mathrm{ml}$ $p<0,001)$. Des Weiteren konnte die TNF- $\alpha$-getriggerte Angpt-2-Ausschüttung durch Kostimulation mit BIFO verringert werden (Veh: 30,3 $\pm 3,8$ vs. BIFO: $22,2 \pm 2,5 \mathrm{ng} / \mathrm{ml}, p<0,01)$. Da BIFO auch im Zell-Lysat Angpt-2 signifikant reduzierte (Veh: 1,00 $\pm 0,23$ vs. BIFO: $0,73 \pm 0,15, p<0,05$ ) mutmaßten wir einen Exozytose-unabhängigen Mechanismus über eine Beeinflussung der Angpt-2-Biosynthese. Die Angpt-2-Transkription (mRNA) war in vivo nach Behandlung von gesunden Tieren mit Bifonazol (Veh: $1,00 \pm 0,38$ vs. BIFO: $0,55 \pm 0,43, p<0,05$ ) verringert.

Schlussfolgerung: Der Endothel-destabilisierende Faktor Angpt-2 kann durch das Antimykotikum BIFO möglicherweise über eine Regulation der Transkription in Endothelzellen reduziert werden und dadurch eine pathologische Hyperpermeabilität hemmen. Neben einer Analyse der Substanz im murinen Sepsismodell erfolgen derzeit Versuche zur weiteren Beschreibung des zugrunde liegenden Mechanismus in vitro.

\section{A quantitative diameter-based approach to analyze microvascular dysfunction in sepsis}

\section{A. Rovas' ${ }^{1}$ J. Sackarnd ${ }^{2}$, H. Pavenstädt ${ }^{1}$, H. Vink ${ }^{3 a}$, P. Kümpers ${ }^{1 a}$}

'Department of Medicine D, Division of General Internal Medicine, Nephrology, and Rheumatology, University Hospital Münster, AlbertSchweitzer-Campus 1, 48149 Münster, Germany; ${ }^{2}$ Department of Cardiology and Angiology, University Hospital Münster, Albert-Schweitzer-Campus 1, 48149 Münster, Germany; ${ }^{3}$ Department of Physiology, Cardiovascular Research Institute Maastricht, Maastricht University, Maastricht, The Netherlands

aboth authors contributed equally.

Purpose: Dysfunctional alterations of the microcirculation play a key role in the development of organ damage in sepsis. Therefore, early detection and monitoring of microvascular alterations has been recognized as an important goal in critical care medicine. In this study, we highlight the importance of a quantitative diameter-based analysis approach.

Methods: This prospective, observational, cross-sectional study included 34 critically ill septic patients (sepsis 3 ) recruited from the intensive care units of a university hospital and 17 healthy volunteers served as controls. We used a sidestream dark field (SDF) camera paired with a data acquisition and analysis software $\left(\right.$ GlycoCheck $\left.^{\text {tix }}\right)$ to assess the sublingual microvessels. About 20 videos (6000 vascular segments) per participant were acquired. Using an automated data analysis, the density of red blood cells contained in microvessels (diameter 5-25 $\mu \mathrm{m}$ ) was quantified and subdivided according to their particular diameter classes ( $1 \mu \mathrm{m}$ each).
Results: In septic patients we observed a statistically significant decrease in the density of capillaries with a diameter of $5 \mu \mathrm{m}$ (D5: $3.7 \mathrm{vs.} 8.6 \mathrm{~mm}^{-2}$, $p=0.002$ ), $6 \mu \mathrm{m}$ (D6: 10.6 vs. $19.7 \mathrm{~mm}^{-2}, p=0.003$ ) and $7 \mu \mathrm{m}$ (D7: 12.8 vs. $\left.22.1 \mathrm{~mm}^{-2}, p=0.006\right)$ compared to healthy controls. Furthermore, D5, D6 and D7 correlated well with several markers of inflammation and critical illness such as lactate (D5: rs $=-0.4, p=0.008$; D6: $r s=-0.4, p=0.007$; D7: $\mathrm{rs}=-0.33, p=0.03$ ), sequential organ failure assessment (SOFA) score (D5: $\mathrm{rs}=-0.49, p=0.0002 ; \mathrm{D} 6: \mathrm{rs}=-0.48, p=0.0003 ; \mathrm{D} 7: \mathrm{rs}=-0.4, p=0.003)$, interleukin-6 (D5: rs $=-0.41, p=0.004 ; \mathrm{D} 6: \mathrm{rs}=-0.4, p=0.006$ ) and procalcitonin (D5: rs $=-0.41, p=0.004 ; \mathrm{D} 6: \mathrm{rs}=-0.39, p=0.006)$. Of note, capillary density in the larger diameter classes of $8-25 \mu \mathrm{m}$ were neither different between patients and controls, nor did they show a meaningful correlation with relevant clinical parameters.

Conclusion: Our data support the hypothesis that microcirculatory impairment in sepsis does not affect all microvessels under $20 \mu \mathrm{m}$, but especially the "real capillaries" with a diameter between 5-7 $\mu \mathrm{m}$. Therefore, a detailed diameter-based assessment of the microvasculature should be evaluated in the future.

\section{Percutaneous decannulation instead of surgical removal for weaning after venoarterial extracorporeal membrane oxygenation-a crossed Perclose ProGlide closure device technique using a hemostasis valve $\mathrm{Y}$ connector}

\section{Orban, E. Lüsebrink, C. Stremmel, S. Massberg}

Intensive Care Unit, Medizinische Klinik und Poliklinik I, Klinikum der Universität München, Munich, Germany

Aim: Improvements in cannula removal techniques and in particular, a standardized decannulation technique with a suitable closure device, are needed to further improve patient outcomes after percutaneous cannulation. The decannulation techniques described so far are neither sufficiently standardized nor proven enough to be used in the large group of venoarterial extracorporeal membrane oxygenation patients. To meet this challenge, we have established a highly standardized and safe decannulation technique based on the Perclose ProGlide closure system (Abbott Vascular).

Methods: Establishment of a highly standardized and safe decannulation technique based on the Perclose ProGlide closure system, which is described in detail with comprehensive instructions for the executive clinician and first application in the context of a pilot study.

Results: So far our technique has already been used successfully in 7 patients since January 2019 as a standard procedure on our intensive care unit (ICU) with only one minor complication after the first procedure, i.e. a small pseudoaneurysm likely originating from antegrade perfusion puncture site which was sealed by thrombin injection.

Conclusions: Our crossed ProGlide technique using a hemostasis valve $\mathrm{Y}$ connector ensuring no blood loss seems to be a very promising decannulation technique.

Key words: decannulation; extracorporeal membrane oxygenation; ProGlide; vascular complications

\section{Isoflurane sedation in patients undergoing VA-ECMO treatment for cardiogenic shock - an observational propensity-matched study}

C. Scherer ${ }^{1,2}$, D. Kupka, , , T. J. Stocker, , D. Joskowiak ${ }^{3}$, H. Scheuplein', C. M. Schönegger ${ }^{1}$,F. Born ${ }^{3}$, C. Stremme ${ }^{1,2}$, E. Lüsebrink ${ }^{1,2}$, K. Stark ${ }^{1,2}$, M. Orban 1,2, T. Petzold ${ }^{1,2}$, S. Peterss ${ }^{3}$, J. Hausleiter ${ }^{1,2}$, C. Hag/ ${ }^{3}$, S. Massberg ${ }^{1,2}$, M. Orban ${ }^{1,2}$

'Intensive Care Unit and Department of Cardiology, University Hospital, LMU Munich, Munich, Germany; ${ }^{2}$ DZHK (German Center for Cardiovascular Research), partner site Munich Heart Alliance, University Hospital, LMU Munich, Munich, Germany; ${ }^{3}$ Department of Cardiac Surgery, University Hospital, LMU Munich, Munich, Germany 
Goal of the study: Neither the feasibility nor the cardiodepressive and vasodepressive effects of isoflurane sedation in patients undergoing venoarterial extracorporeal membrane oxygenation (VA-ECMO) treatment for cardiogenic shock have been investigated. As the vast majority of patients with severe cardiogenic shock treated with VA-ECMO are unconscious and mechanically ventilated, the question arises to what extent a volatile sedation strategy using isoflurane is feasible in these patients, impacts the ventilation duration and intensive care unit (ICU) stay, influences catecholamine dosages and VA-ECMO flow support, and impacts treatment costs. Methods: A total of 32 cardiogenic shock patients with VA-ECMO treatment under sedation with volatile isoflurane on our cardiac ICU were enrolled in this retrospective single center study and were matched by propensity score in a 1:1 ratio with intravenously (IV) sedated patients. Results and discussion: In this study 32 patients in our registry treated with VA-ECMO were sedated with isoflurane. The mean age of the patients was $58.4 \pm 13.8$ years for conventional sedation and $56.3 \pm 11.5$ years for isoflurane sedation $(p=0.51)$. Administration of isoflurane was associated with lower IV sedative drug use during VA-ECMO treatment (86\% versus $32 \%$, $p=0.01)$. Mean systolic arterial pressure was similar $(94.3 \pm 12.6 \mathrm{mmHg}$ versus $92.9 \pm 10.5 \mathrm{mmHg}, p=0.65$ ), but mean heart rate was significantly higher in the conventional sedation group in contrast to the isoflurane group $(85.2 \pm 20.5 / \mathrm{min}$ versus $74.7 \pm 15.0 / \mathrm{min} ; p=0.02)$. Importantly, catecholamine dose, VA-ECMO blood flow and VA-ECMO gas flow during the first 5 days, ventilation time of survivors $(304 \pm 143 \mathrm{~h}$ versus $398 \pm 272 \mathrm{~h}, p=0.16)$, bleeding complications at least classified as BARC3a or higher $(59.3 \%$ versus $65.3 \%, p=0.76)$ and 30 -day mortality $(59.2 \%$ versus $63.4 \%, p=0.80$ ) were similar in both groups. The overall sedation cost per patient was significantly lower in the conventional group in comparison to the isoflurane group $(537 \pm 624 €$ versus $1280 \pm 837 €, p<0.001)$. Conclusion: Volatile sedation with isoflurane is feasible, albeit with higher costs, in patients with cardiogenic shock and VA-ECMO treatment and was not associated with higher catecholamine dosage and ECMO flow rate compared to IV sedation.

\section{Herz-Kreislauf-Stillstand auf der Intensivstation: Charakteristika und Outcome}

\section{K. Roedl, R. Blohm, D. Jarczak, V. Fuhrmann, G. Söffker, S. Kluge}

Klinik für Intensivmedizin, Universitätsklinikum Hamburg-Eppendorf, Hamburg, Deutschland

Zielsetzung ("goal of the study"): Kritisch kranke Patienten auf der Intensivstation (ICU) können einen Herz-Kreislauf-Stillstand (HKS) erleiden. Die Notwendigkeit einer kardiopulmonalen Reanimation (CPR) bei kritisch kranken Patienten ist mit einer hohen Mortalität vergesellschaftet. Zielsetzung dieser Studie war es, die Häufigkeit, die Charakteristika und das Outcome bei HKS und CPR auf der ICU zu untersuchen.

Methode (,methods"): Über einen 1-Jahres Zeitraum (01/2017-01/2018) konnten prospektiv an der Klinik für Intensivmedizin des Universitätsklinikums Hamburg-Eppendorf 176 Patienten mit erstmaligem HKS und CPR im Rahmen des Intensivstationsaufenthaltes identifiziert werden. Es wurden die Patientencharakteristika, Aufnahmediagnose, Schwere der Erkrankung und ICU-Mortalität erhoben.

Ergebnisse und Diskussion („,results and discussion“): Von insgesamt 7690 Patienten, welche während des Studienzeitraumes intensivmedizinisch behandelt wurden, erlitten 176 Patienten erstmalig einen HKS auf der ICU mit folgender CPR. Die Patienten waren zu $63 \%(n=111)$ männlich und median 70 (58-78) Jahre alt. Die Patienten waren vor dem HKS median 3 (1-8) Tage in intensivmedizinischer Betreuung. Vor dem HKS waren $57 \%$ $(n=100)$ sediert, $63 \%(n=110)$ mechanisch beatmet, $70 \%(n=123)$ unter Katecholamintherapie, und $27 \%(n=48)$ erhielten eine Nierenersatztherapie. Der mediane SOFA- und SAPS II-Score vor HKS betrug 10 (7-12) und $42(34-53)$ Punkte. Der HKS ereignete sich in $49 \%(n=87)$ der Fälle innerhalb der ersten $48 \mathrm{~h}$ nach ICU-Aufnahme. Die Ursache der HKS war in $24 \%(n=42)$ kardialer Genese. Der Erstrhythmus war schockbar (VT/VF) in $23 \%(n=40)$ der Fälle. Ein durchgehendes Wiedererlangen des Kreislaufes konnte in $80 \%(n=140)$ der Patienten erzielt werden. Zeit bis zur Wie- dererlangung des Kreislaufes (ROSC) war median 2 (1-5) min. Ein erneuter Herz-Kreislauf-Stillstand im Rahmen des ICU-Aufenthaltes wurde bei $26 \%(n=45)$ der Patienten beobachtet. Insgesamt überlebten $34 \%(n=60)$ der Patienten nach HKS den ICU-Aufenthalt, davon ein Großteil (75\%, $n=46)$ mit gutem neurologischem Outcome (CPC I/II) nach Reanimation. Schlussfolgerung (",conclusion“): Das Auftreten eines HKS auf der ICU ist mit einer hohen Mortalität vergesellschaftet. Der HKS ereignet sich in etwa der Hälfte der Fälle innerhalb der ersten 48 h nach ICU-Aufnahme und ist selten kardialer Genese.

\section{High to low bicarbonate replacement fluid switch in alkalotic patients during continuous venovenous hemofiltration with regional citrate anticoagulation-a retrospective single centre analysis}

\section{P. Köglberger, S. J. Klein, M. Joannidis}

Division of Intensive Care and Emergency Medicine, Department of Internal Medicine, Medical University Innsbruck, Innsbruck, Austria

Goal of the study: The aim of our study was to compare the replacement fluids (RF) Phoxilium (30 mmol/l HCO3-) and Biphozyl $(22 \mathrm{mmol} /$ 1 HCO3-) during continuous renal replacement therapy (CVVH) with regional citrate anticoagulation (RCA) in alkalotic critically ill patients. Consequently, we hypothesized that the HCO3-, hypothesis 1 (H1), BE $(\mathrm{H} 2)$ and $\mathrm{CO}_{2}(\mathrm{H} 3)$ levels would significantly decrease after the RF change (Phoxilium to Biphozyl), with the $\mathrm{pH}(\mathrm{H} 4)$ stabilizing thereafter at physiological levels.

Methods: This retrospective study evaluated intensive care unit patients who underwent CVVH with RCA between 2016 and 2017. Patients were eligible for inclusion if they were 1 ) aged $\geq 18$ years, 2) admitted to ICU, had 3) the indications for CVVH as determined by the attending physician, 4) a change of replacement fluid from Phoxilium ${ }^{\star}$ to Biphozyl ${ }^{\oplus}$ based on a persistent blood $\mathrm{HCO} 3$-concentration $\geq 26 \mathrm{mmol} / \mathrm{l}$. Patients were excluded in case of CVVH duration less than $48 \mathrm{~h}$ and $<12 \mathrm{~h}$ of CVVH treatment duration with Phoxilium ${ }^{\otimes}$ as well as Biphozyl $l^{\oplus}$. Overall targeted observation period including data collection was from $-72 \mathrm{~h}$ until $+72 \mathrm{~h}$ around RF switch. Student's t-test was used to test $\mathrm{H}$ 1-4. All tests were 2 -sided (significance level 5\%).

Results: In the study 42 (27 male, 15 female, mean age 57 years, BMI 26) out of $153 \mathrm{CVVH}-\mathrm{RCA}$ patients were eligible for analysis. After switching the RF the mean $\mathrm{HCO} 3-[\mathrm{H} 1]$ significantly decreased from $27.9 \mathrm{mmol} / \mathrm{l}$ (SD \pm $1.4 \mathrm{mmol} / \mathrm{l})$ to $26.0 \mathrm{mmol} / \mathrm{l}(\mathrm{SD} \pm 2.7 \mathrm{mmol} / \mathrm{l})$ within $24 \mathrm{~h}(p=0.001)$. The mean $\mathrm{BE}[\mathrm{H} 2]$ significantly decreased from $4.1 \mathrm{mmol} / \mathrm{l}(\mathrm{SD} \pm 1.5 \mathrm{mmol} / \mathrm{l})$ to $1.8 \mathrm{mmol} / \mathrm{l}(\mathrm{SD} \pm 3.1 \mathrm{mmol} / \mathrm{l})$ within $24 \mathrm{~h}(p=0.001)$. The mean $\mathrm{PaCO}_{2}$ [H3] decrease from $43.6 \mathrm{mmHg}(\mathrm{SD} \pm 5.3 \mathrm{mmHg}$ ) to $41.2 \mathrm{mmHg}$ (SD \pm $7.1 \mathrm{mmHg}$ ) within $24 \mathrm{~h}$ was not significant $(p=0.138)$. During the RF change the mean $\mathrm{pH}[\mathrm{H} 4]$ was $7.43(\mathrm{SD} \pm 0.05)$ and did not change significantly for at least $72 \mathrm{~h}(\mathrm{pH} 7.43, \mathrm{SD} \pm 0.05)$ thereafter $(p=0.802)(\bullet$ Fig. 1). Conclusions: Switching from high to low bicarbonate RF in alkalotic patients during CVVH with RCA seems to be an appropriate approach for acid-base control, although the $\mathrm{PaCO}_{2}$ was not significantly decreased. Further research is warranted.

\section{Gender differences in acid-base metabolism during continuous venovenous hemofiltration with regional citrate anticoagulation}

\section{P. Köglberger, S. J. Klein, M. Joannidis}

Division of Intensive Care and Emergency Medicine, Department of Internal Medicine, Medical University Innsbruck, Innsbruck, Austria

Goal of the study: The aim of our study was to compare the replacement fluids (RF) Phoxilium (30 mmol/l HCO3-) and Biphozyl (22 mmol/l HCO3-) during continuous renal replacement therapy $(\mathrm{CVVH})$ with regional citrate anticoagulation (RCA) in alkalotic critically ill women and men. It was hypothesized that the HCO3- (hypothesis h 1 ), base excess (BE) (h 2) and $\mathrm{pH}$ (h 3 ) levels as well as the death rate at 90 days (h 4) dif- 

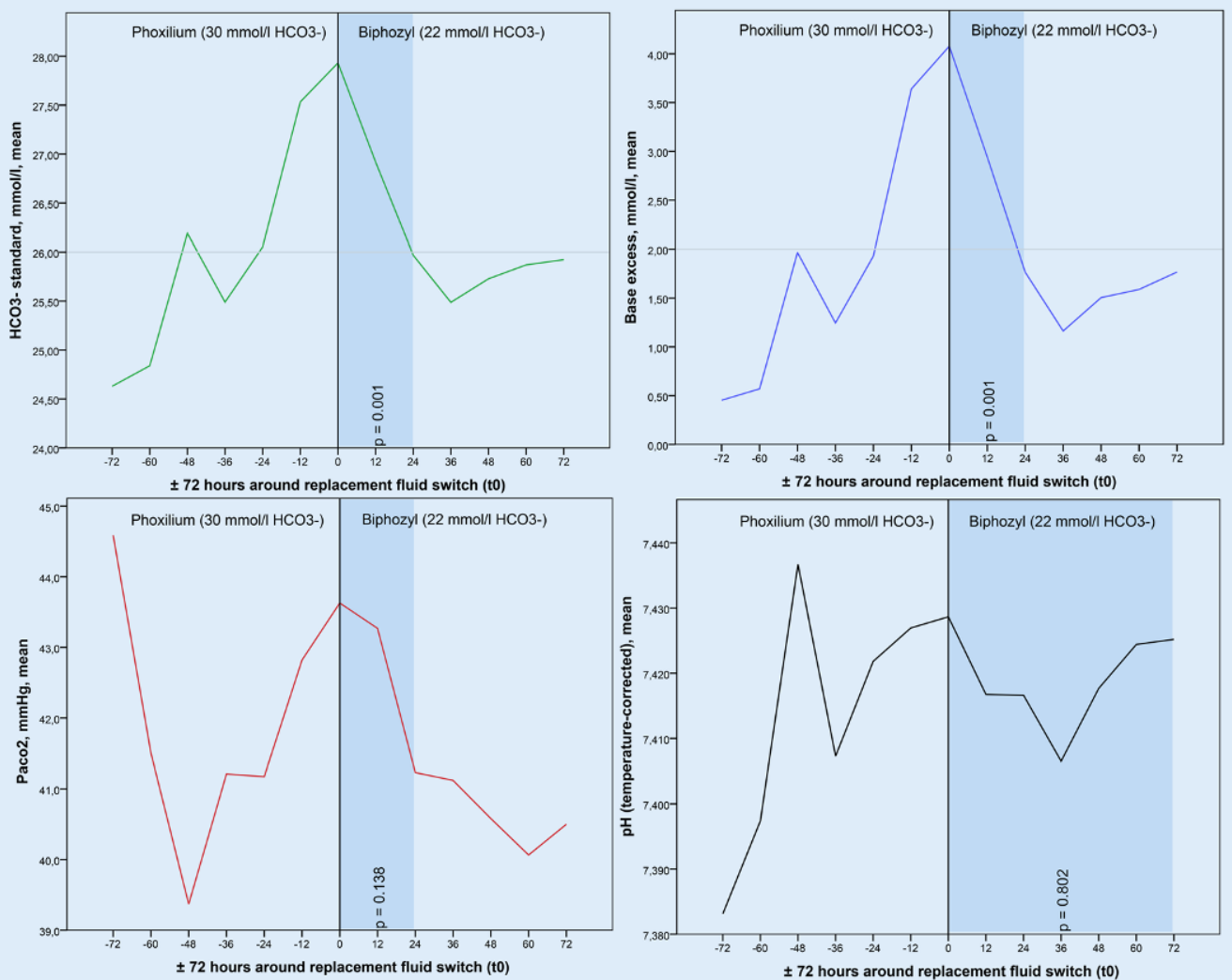

Fig. $1<$ (zu „,High to low bicarbonate replacement fluid switch in alkalotic patients during continuous venovenous hemofiltration with regional citrate anticoagulation-a retrospective single centre analysis") Trends of $\mathrm{HCO} 3-, \mathrm{BE}, \mathrm{PaCO} 2$ and $\mathrm{pH}$ over $72 \mathrm{~h}$ before and after switching (to) the replacement fluid from Phoxilium $^{\circledast}$ to Biphozy ${ }^{\circledR}$

fered between alkalotic women and men during CVVH-RCA therapy with Phoxilium and Biphozyl.

Methods: This retrospective study evaluated intensive care unit patients who underwent CVVH with RCA between 2016 and 2017. Patients were found eligible for inclusion if they were 1) aged $\geq 18$ years, 2) admitted to ICU, had 3) the indications for CVVH as determined by the attending physician, 4) a change of RF from Phoxilium ${ }^{\oplus}$ to Biphozyl ${ }^{\circ}$ based on a persistent blood HCO3- concentration $\geq 26 \mathrm{mmol} / \mathrm{l}$. Patients were excluded in case of CVVH duration less than $48 \mathrm{~h}$ and $<12 \mathrm{~h}$ of CVVH treatment duration with Phoxilium $^{\circledR}$ as well as Biphozyl ${ }^{\oplus}$. Overall targeted observation period including data collection was $\pm 72 \mathrm{~h}$ from the switch of the RF. Mann-Whitney U-test and Student's t-test was used to test h 1-3, KaplanMeier method and logrank test was used for $\mathrm{h} 4$. All tests 2-sided.

Results: In this study 42 of $153 \mathrm{CVVH}-\mathrm{RCA}$ patients were eligible for analysis. Of these 15 (35\%) were women (mean age 57 years, height $166 \mathrm{~cm}$, median weight $72 \mathrm{~kg}$, BMI 27) and 27 (64\%) men (mean age 57 years, height $177 \mathrm{~cm}$, median weight $74 \mathrm{~kg}$, BMI 25). During therapy with Phoxilium HCO3- $(p=0.011, \mathrm{~h} 1)$ and $\mathrm{BE}(p=0.005, \mathrm{~h} 2)$ levels differed significantly $(p<0.05)$ between women and men, whereas $\mathrm{pH}(p=0.181, \mathrm{~h} 3)$ did not. During therapy with Biphozyl HCO3- $(p=0.650, \mathrm{~h} 1), \mathrm{BE}(p=0.545$, h $2)$ and $\mathrm{pH}(p=0.578, \mathrm{~h} 3)$ did not differ significantly between women and men. Mortality at 90 days $(p=0.966, \mathrm{~h} 4)$ showed no significant difference between women and men (• Fig. 1).

Conclusions: We found significant differences for $\mathrm{HCO} 3-$ and $\mathrm{BE}$ levels during therapy with Phoxilium in alkalotic critically ill women and men, without an effect based on the volume of distribution. Since no significant differences between women and men were found during therapy with Biphozyl, this possibly indicates that RF with lower $\mathrm{HCO} 3$ - concentrations may be beneficial for both sexes; however, we did not find significant differences in mortality. Further research is warranted.

\section{Sex differences in critically ill patients with acute kidney injury}

\section{S. J. Klein, P. Köglberger, M. Joannidis}

Division of Intensive Care and Emergency Medicine, Department of Internal Medicine, Medical University Innsbruck, Innsbruck, Austria

Background: Acute kidney injury (AKI) is a major problem in critically ill patients admitted to an intensive care unit (ICU) causing both high mortality and morbidity. The aim of this study was to explore sex differences in critically ill patients admitted to an ICU who had at least one episode of AKI

Methods: All patients admitted to the ICU of the University Hospital Innsbruck between 1- January 2015 and 31 December 2018 were eligible for inclusion, if they developed at least one AKI episode after ICU admission. Severity of AKI was categorized according to KDIGO. The study was approved by the local ethics committee (\# 1054/2018).

Results: Out of 1970 patients, 469 (150 women, 319 men) with 482 ICU admissions were eligible for inclusion. Mean age was 62.85 years $( \pm 17.27$ years) for women and 65.64 years $( \pm 12.81$ years) for men $(p=0.07)$. In total, they suffered from 517 AKI episodes.

Median duration of ICU stay was 5.82 days (95\% CI 3.01-11.96 days) for women and 6.07 days ( $95 \%$ CI 3.13-13.11 days) for men ( $p=0.33$ ). Median duration of each AKI episode was 77.34 h (95\% CI 45.48-144.51 h) for women and $71.52 \mathrm{~h}(95 \% \mathrm{CI} 45.64-158.2 \mathrm{~h})$ for men $(p=0.8)$. The ICU mortality was $8.7 \%$ for women and $22.2 \%$ for men, while hospital mortality was $11.4 \%$ for women and $26.1 \%$ for men. Women had a lower hazard ratio (HR) for death in ICU of $0.87(95 \%$ CI $0.60-1.24 ; p=0.43)$ and for death in hospital (HR 0.9, 95\% CI 0.66-1.24; $p=0.54$ ). Renal replacement therapy (RRT) requirement was $9.1 \%$ in women and $20.7 \%$ in men $(p=0.8)$. Maximum AKI severity was approximately the same for women and men (KDIGO 1: $44.4 \%$ vs. $48.6 \%$; KDIGO 2: $14.4 \%$ vs. $10.6 \%$, KDIGO 3: $41.2 \%$ vs. $40.1 \%$ for women and men, respectively; $p=0.796$ ).

Maximum creatinine differed significantly between women and men (mean $2.23 \pm 1.59$ vs. $2.48 \pm 1.58 ; p<0.01$ ), as well as maximum cystatin 


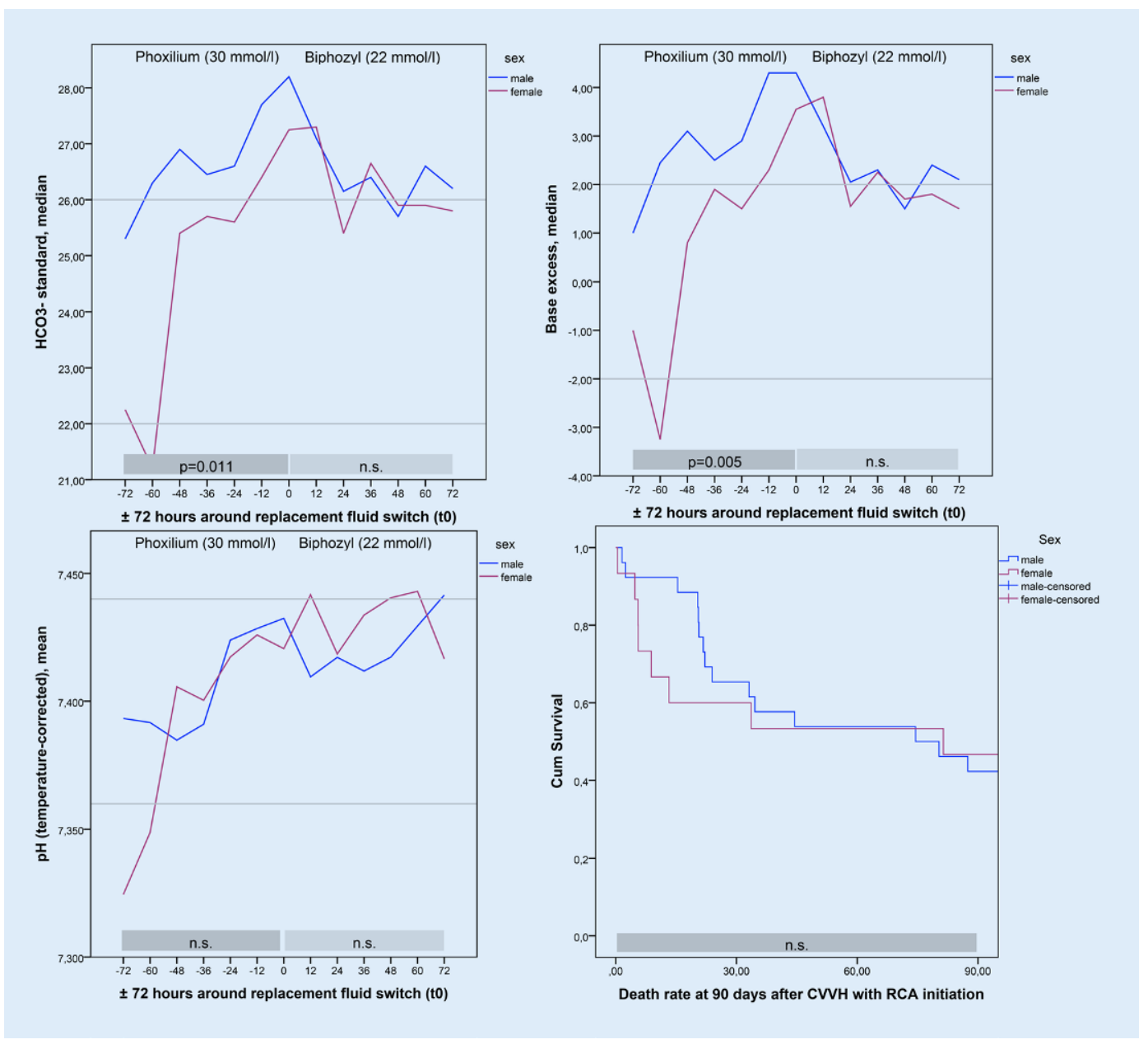

Fig. $1<$ (zu ,Gender differences in acidbase metabolism during continuous venovenous hemofiltration with regional citrate anticoagulation“) Trends of $\mathrm{HCO} 3-, \mathrm{BE}$ and $\mathrm{pH}$ over $72 \mathrm{~h}$ before and after switching ( $\mathrm{t} 0$ ) the replacement fluid from Phoxilium $^{\circledast}$ to Biphozyl ${ }^{\circledast}$ as well as of survival rates (F/M)

C (mean $2.48 \pm 1.18$ vs. $2.36 \pm 1.14 ; p<0.01)$. Glomerular filtration rates (GFR) also showed significant differences between women and men when derived from creatinine (mean $41.88 \pm 22.1$ vs. $43.41 \pm 18.76$; $p<0.01$ ) and from cystatin C (mean $31.79 \pm 19.48$ vs. $31.86 \pm 16.73 ; p<0.01)$.

Conclusion: While most assessed parameters showed no significant differences between women and men, both maximum creatinine and maximum cystatin $\mathrm{C}$ and their correspondingly minimum GFRs were significantly different between both sexes. This is an important finding, since the same creatinine criteria are considered for staging of AKI, independent of possible influencing factors on creatinine, such as muscle mass.

\section{Sex-related differences in intraoperative cerebral autoregulation during major noncardiac surgery}

U. Harler, N. Juilfs, C. Rademacher, C. Zoellner, M. Fischer

Department of Anesthesiology, University Medical Center HamburgEppendorf, Hamburg, Germany

Background: Cerebral autoregulation (CA) is a mechanism that keeps cerebral blood flow (CBF) constant over a wide range of blood pressures, thereby ensuring the high metabolic demand of the brain $[1,2]$. Previous studies have shown better cerebrovascular reactivity, and higher blood flow velocities in women under various conditions [3-5]; however, sex-related differences in CA in the perioperative setting are widely unexplored despite their potential impact on an individualized hemodynamic management. Therefore, this study aimed to investigate sex-related differences in CA in patients undergoing major noncardiac surgery with the patient under general anesthesia.
Methods: This was a post hoc analysis of 62 patients $(29$ female and 33 male) from a prospective study, which investigated the potential influence of altered CA on the incidence of postoperative cognitive disorders (POCD) after major noncardiac surgery with the patient under general anesthesia. Patients enrolled in this study were aged 60 years or older and had no history of cerebrovascular or neurodegenerative disease. The CA monitoring was performed using continuous measurement of the cerebral oximetry index (COx) from incision to closure, where $\mathrm{COx}$ represents the moving correlation coefficient between near infrared spectroscopy (NIRS) based measurement of regional cerebral oxygen saturation and mean arterial blood pressure (MAP). For data processing and COx calculation the $\mathrm{ICM}+$ software (University of Cambridge, Cambridge, UK) was used. A $\mathrm{COx}<0.3$ indicated intact $\mathrm{CA}$, whereas a $\mathrm{COx} \geq 0.3$ indicated impaired CA and represents an increasing correlation between CBF and MAP. The association of gender with intraoperative $\mathrm{COx}$ and variables that were considered clinically relevant were analyzed with multivariate analysis.

Results: The time with $\mathrm{COx} \geq 0.3$ was significantly higher in male patients (males, 42.6\%, IQR 35.9-49.5); females, 32.9\%, IQR 26.1-42.4, $p=0.007$ ). Average COx during the monitored time period was also higher in men (males, 0.19, IQR 0.11-0.26); females, 0.07, IQR 0.01-0.19, $p=0.02$ ). Male gender was significantly associated with impaired CA in the multivariable analysis $(B=-7.667,95 \% \mathrm{CI}:-13.506 ;-1.827, p=0.011)$. Interestingly, there were no significant differences in average MAP, maximum MAP and minimum MAP between men and women.

Conclusion: Women demonstrated better intraoperative CA at the same intraoperative MAP levels as men. Our findings underline the importance of individualized blood pressure targets that may be sex-dependent. Future clinical studies investigating the impact of our findings on perioperative neurological outcome are urgently needed. 


\section{References}

1. Meng L, Gelb AW (2015) Regulation of cerebral autoregulation by carbon dioxide. Anesthesiology 122(1):196-205

2. Armstead WM (2016) Cerebral blood flow autoregulation and dysautoregulation. Anesthesiol Clin. 2016;34(3):465-477

3. Kastrup A, Thomas C, Hartmann C, Schabet M (1997) Sex dependency of cerebrovascular $\mathrm{CO} 2$ reactivity in normal subjects. Stroke 28(12):2353-2556

4. Ackerstaff RG, Keunen RW, van Pelt W, Montauban van Swijndregt AD, Stijnen $T$ (1990) Influence of biological factors on changes in mean cerebral blood flow velocity in normal ageing: a transcranial Doppler study. Neurol Res 12(3):187-191

5. Deegan BM, Sorond FA, Galica A, Lipsitz LA, O'Laighin G, Serrador JM (2011) Elderly women regulate brain blood flow better than men do. Stroke 42(7):1988-1993

\section{Seltene Ursache zerebraler Ischämien: Intraarterielle Fehllage eines ZVK - Ein Fallbericht}

\section{J. Kronisch, K. Jürgens, P. Lebiedz}

Klinik für Innere Medizin und internistische Intensivmedizin, Evangelisches Krankenhaus Oldenburg, Medizinischer Campus Universität Oldenburg, Oldenburg, Deutschland

Hintergrund: Die Anlage zentralvenöser Zugänge (ZVK) ist ein Standardeingriff in der Notfall- und Intensivmedizin. Komplikationen treten selten auf, können aber schwerwiegend ausfallen.

Im klinischen Alltag hat sich eine Lagekontrolle mittels EKG-Ableitung sowie Röntgen-Thorax etabliert.

Fallbericht: Wir berichten den Fall einer 41-jährigen Patientin, die bei bekannter Polytoxikomanie aufgrund einer Pneumonie im Rahmen einer Entzugsbehandlung intubationspflichtig wurde. Bei hämodynamischer Instabilität wurde ein ZVK über die rechte Halsseite angelegt und eine Katecholamintherapie begonnen. Ein Röntgen-Thorax ( $\bullet$ Abb. 1) zeigte eine scheinbar regelrechte Katheterlage mit Ende in der oberen Thoraxapertur. Nach Stabilisierung kam es am Folgetag zu fokalen epileptischen Anfällen. Eine CCT zeigte multiple bilaterale Ischämien, weshalb die Patientin in unsere Universitätsklinik für Neurologie übernommen wurde.

Auf unserer Intensivstation fiel ein pulsatiler Rückfluss aus den ZVK-Lumen auf, sonographisch stellte sich eine intraarterielle Lage in der rechten ACI/ACC dar (- Abb. 1). Der ZVK wurde entfernt und eine antikonvulsive Therapie begonnen. Die Patientin konnte nach Extubation im Verlauf mit einer homonymen Hemianopsie sowie Konzentrations- und räumlicher Orientierungsstörung in eine Rehabilitationsklinik verlegt werden. Diskussion: Im dargestellten Fall kam es durch die intraarterielle Lage und Katecholamintherapie zu multiplen zerebralen Ischämien. In der Literatur gibt es einzelne Fallserien über die seltenen neurologischen Komplikationen $(<1 \%)$ nach ZVK-Anlage [2].

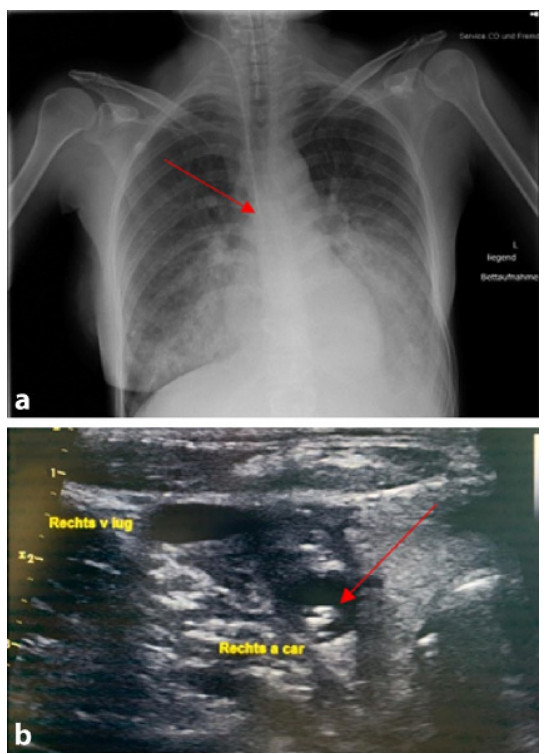

Abb. $1<$ a RöntgenThorax nach ZVK-Anlage; ZVK-Spitze: roter Pfeil. b Sonographie der Halsgefäße rechts nach Übernahme; ZVK: roter Pfeil
Üblicherweise erfolgt eine Lagekontrolle mittels Röntgen-Thorax sowie EKG-Ableitung, doch auch hier kann eine fehlerhafte Lage nicht ausgeschlossen werden [3].

Die Komplikationsraten können durch sonographisch gesteuerte Punktion deutlich $(8,7 \%$ vs. $1,8 \%)$ reduziert werden, auch eine sonographische Lagekontrolle des Seldinger-Drahtes und des Katheters ist so möglich [1].

\section{Literatur}

1. Wigmore et al (2007) Effect of the implementation of NICE guidelines for ultrasound guidance on the complication rates associated with central venous catheter placement in patients presenting for routine surgery in a tertiary referral centre. $\mathrm{Br}$ J Anaesth 99(5):662-665

2. Katyal et al (2018) Inadvertent central arterial catheterization: an unusual cause of ischemic stroke. J Neurosci Rural Pract 9(1):155-158

3. Urban et al (2011) Intra-arterial ECG leads of a positive P-wave potential during central venous catheterization. Anasthesiol Intensivmed Notfallmed Schmerzther 46(2):94-97

\section{Hirninfarkt als Erstsymptom - Fallbeschreibung eines Patienten mit intramuraler dissezierender Hämorrhagie}

\section{N. Schenker, H. van der Schalk, M. Bohné, S. Willems, E. Bahlmann \\ 2. Med. Klinik, Asklepios Klinik St. Georg, Hamburg, Deutschland}

Die intramyokardiale dissezierende Hämorrhagie (IDH) ist eine sehr seltene Komplikation nach Myokardinfarkt, verbunden mit hoher Mortalitätsrate insbesondere bei konservativem Management. Wir berichten über einen 54-jährigen Mann, welcher mit einem rechtsseitigen Mediainsult in unserer Notaufnahme vorstellig wurde. Im EKG zeigte sich ein subakuter Myokardinfarkt. Die in transthorakaler Echokardiographie dargestellte intramyokardiale dissezierende Hämorrhagie des linksventrikulären Apex bestätigte sich in kardialer Computertomographie und Magnetresonanztomographie. Anhaftende biventrikuläre Thrombusbildungen zeigten sich in initialer Echokardiographiediagnostik. Ein sofortiger Thrombektomieeingriff wurde durch eine auftretende intrazerebrale Blutung mit konsekutiver Hemikraniektomie kompliziert. Eine koronare 1-Gefäß-Erkrankung mit Verschluss der linken Herzkranzarterie wurde konservativ behandelt. Nach einer Nachverfolgung von 3 Monaten kam es unter initiierter Antikoagulationsbehandlung zur Resolution der intramyokardialen dissezierenden Hämorrhagie und zur Auflösung der Thrombusformationen. Der Patient war klinisch stabil, und der neurologische Status besserte sich zunehmend. Pathophysiologie, Diagnostik und Management dieser Komplikation mit potenziell hoher Letalität werden im Review dargestellt.

\section{Safety of percutaneous dilatational tracheotomy in patients on dual antiplatelet therapy and anticoagulation}

\section{Orban, E. Lüsebrink, K. Stark, S. Massberg}

Intensive Care Unit, Medizinische Klinik und Poliklinik I, Klinikum der Universität München, Munich, Germany

Objective: Percutaneous dilatational tracheotomy has become a routine procedure in intensive care units (ICUs); however, given the high and steadily growing number of patients receiving anticoagulation, dual antiplatelet therapy, or even a combination of both (also known as triple therapy), there are concerns about the safety of the procedure, in particular for critically ill patients with a high risk of bleeding. In this retrospective study, we investigated whether percutaneous dilatational tracheotomy in this high-risk population was associated with elevated procedural complications.

Design: Retrospective single center study with analysis of all percutaneous dilatational tracheotomies performed in our cardiac ICU from January 2018 to May 2019.

Setting: Munich University Hospital cardiac ICU.

Patients and Interventions: a total of 34 patients who underwent percutaneous dilatational tracheotomy according to the Ciaglia technique with accompanying bronchoscopy in our cardiac ICU from January 2018 to May 2019 were included. Patients were stratified into clinically relevant risk groups based on anticoagulation and antiplatelet therapy considering 
standard laboratory coagulation parameters, i. e. activated partial thromboplastin time, international normalized ratio, and platelet count with differentiated analysis of procedure-related complications in each risk group until hospital discharge.

Measurements and main results: A total of 34 patients who underwent percutaneous dilatational tracheotomy were included and assigned to 5 clinically relevant treatment groups: IV unfractionated heparin (prophylactic dosage, $n=4$ ), IV unfractionated heparin (therapeutic dosage, $n=4$ ), aspirin and IV unfractionated heparin (therapeutic dosage, $n=7$ ), dual antiplatelet therapy with IV unfractionated heparin (prophylactic dosage, $n=5$ ), and dual antiplatelet therapy with IV unfractionated heparin (therapeutic dosage, $n=14$ ).

Bleedings without surgical intervention or blood transfusion was documented in three patients in the whole cohort, but no bleeding occurred in the triple therapy group. These were exclusively caused by skin bleeding at the immediate puncture site, each of which could be easily treated with one or two single stitches. There were no severe bleeding complications or potentially life-threatening procedure-related complications. Additionally, the rate of complications in patients with elevated body mass index was not increased.

Conclusions: Bronchoscopy-guided percutaneous dilatational tracheotomy according to the Ciaglia technique with careful consideration of all potential indications and contraindications may be a safe and low-complication procedure for airway management, even in patients receiving dual antiplatelet therapy and therapeutic anticoagulation simultaneously in our cohort with a high risk of bleeding.

\section{Therapie einer extremen Anämie mit vernetztem Rinderhämoglobin - ein Fallbericht}

\section{T. S. Meisel, A. Meiser, M. Schöder, H. Knoll, T. Volk}

Interdisziplinäre Operative Intensivstation, Klinik für Anästhesiologie, Intensivmedizin und Schmerztherapie, Universitätsklinikum des Saarlandes, Homburg/Saar, Deutschland

Wir berichten über eine 29-jährige Zeugin Jehovas, die nach Spontanabort in der 25. Schwangerschaftswoche ein akutes Nierenversagen und eine schwere Anämie bedingt durch Blutverlust und Hämolyse erlitt. Trotz Umsetzung aller Empfehlungen des „patient blood management" fiel der Hämoglobinwert $(\mathrm{Hb})$ kontinuierlich ab. An Tag 10 wurde sie bei $\mathrm{Hb}$ 1,9 g/ dl plötzlich bewusstlos und musste intubiert und beatmet werden. Wegen organprotektiver Effekte und der guten Steuerbarkeit wurde sie inhalativ mit Isofluran sediert. Isofluran ermöglichte jeweils eine rasche neurologische Beurteilbarkeit in Sedierungsfenstern sowie eine regelmäßige, ruhige Spontanatmung bei tiefer Sedierung mit reduziertem Sauerstoffverbrauch. Als Ausdruck einer posthypoxischen Enzephalopathie zeigte sie in den Sedierungsfenstern Krampfanfälle, die im EEG bestätigt und antikonvulsiv behandelt wurden. Bei $\mathrm{Hb}$ 1,8 g/dl erhielt sie 2 Infusionsbeutel mit polymerisiertem bovinem Hämoglobin (Hemopure, $\mathrm{HbO} 2$ Therapeutics LLC, Souderton, PA, USA), wegen der kurzen Halbwertszeit mehrmals wiederholt an den Folgetagen. Eine beachtliche Methämoglobinämie wurde festgestellt. Auch nach Abzug des Met-Hb zeigte das Gesamt-Hb Anstiege um $0,4-0,8 \mathrm{~g} / \mathrm{dl}$ nach den Gaben. Die Sauerstofftransportkapazität konnte damit initial um 33\% gesteigert werden. Es kam zu einer vollständigen neurologischen Erholung, und die Patientin wurde schließlich vom Respirator entwöhnt, jedoch weiterhin dialysepflichtig nach 38 Tagen in eine andere Klink verlegt.

Schlussfolgerung: Wenn die Gabe von Fremdblut keine Option darstellt, kann durch Gabe von polymerisiertem bovinem Hämoglobin als UltimaRatio-Therapie die Sauerstofftransportkapazität vorübergehend erhöht werden. Eine inhalative Sedierung mit Isofluran zur Senkung des Sauerstoffverbrauchs. 